\title{
"ZAVEDAM SE, DA SO STVARI, KI JIH LAHKO NAREDIM ZADNJIČ“ Od režiserke do plesalke
}

Lindy Dannelly je mama, igralka in plesalka iz Atlante. Doštudirala je režijo ter se kot igralka ves čas izpopolnjevala v plesu in petju, kar je pomembno za poklic na odrskih deskah. Bila je ustanoviteljica in vodja gledališča Koalty Presentations v Atlanti ter tudi ena izmed direktorjev Atlanta Classical Theatra. Nastopala in režirala je več kot 20 let, potem pa je ugotovila, da je vedno bolj utrujena in da ne zmore vsega fizičnega napora. Bolezen sklepov jo je sprva primorala uporabljati bergle, a te so jo še bolj utrudile. Pustila je delo $v$ gledališč in odprla čistilni servis, da bi preživela. Nazadnje je začela uporabljati invalidski voziček. Zaprla je čistilni servis in se vrnila na oder, tokrat s plesom.

\section{Koliko si bila stara, ko si začela uporabljati voziček?}

Stara sem bila 45 let, in ker zdravniki niso natančno poznali moje diagnoze, so mi dali začasen voziček, ki je bil rabljen. To je bil res slab voziček, približno kot nakupovalni voziček z zlomljenim koleščkom. Tako kot se prvič usedeš v avto in se moraš navaditi na prestave in pedala, tako sem se morala naučiti uporabljati voziček. Doma še vedno uporabljam bergle in avto še vedno lahko vozim, za vse preostalo pa moram uporabljati invalidski voziček.

Gledališče in ples sta si blizu, pa vendar si postala plesalka, ko si dobila diagnozo, in ne v najmlajših letih.

Vedno sem bila zelo dejavna in sem se poleg gledališča ukvarjala še z raznimi športi. Tek je bil moja strast in odlična sprostitev od gledališkega dela. Nisem si predstavljala, da bi zaradi bolezni obsedela doma pred televizijo. Bi se mi zmešalo! Leta zame niso ovira, letos bom dopolnila 50 let in ples zahteva dobro fizično kondicijo. Ko sem dobila voziček, sem si kupila še sobno kolo in nekaj uteži, ko lahko, hodim še na plavanje.

\section{Že tri leta si članica profesionalne inkluzivne plesne skupine Full Radius Dance.}

Že prej sem vedela za to plesno skupino v Atlanti in sem jih spremljala, nisem pa vedela, da bom jaz tista, ki bo na vozičku, in da bom plesala z njimi. Najprej sem hodila na njihove tečaje, da sem se naučila osnov in nekaj tehnike. Ni bilo najlažje delo zame! Nisem ravno uživala v plesu, ker sem bila v vozičku okorna. A verjetno je bilo tega več v moji 
glavi, ker sem še vedno upala, da bo šlo nekega dne brez vozička in bom spet stopila na noge. Douglas je bil zelo potrpežljiv, in ko sem ugotovila, kako se lahko zavrtim in pridobim hitrost, sem šele začutila, da lahko plešem. Po enem letu sem se prijavila na avdicijo in uspela. Takrat se je šele začelo pravo učenje in fizični napor.

Še vedno ob besedi ples pomislim na dve različni stvari. Ena je, ko grem s prijatelji ven v bar in plešem, kot jaz hočem in zmorem, ko plešem doma v kuhinji ali samo migam z glavo. To je tista svoboda gibanja, ki jo imamo vsi. Druga zgodba je ples, ki je zdaj tudi moja služba. Treniramo trikrat na teden po štiri ure, in če so nastopi, tudi več. Nisem samo jaz, ampak tudi moji soplesalci in vozički. Svoboda gibanja je mogoče omejena s koreografijo in ne z mojo invalidnostjo. Najbolj me zanima to, kaj lahko naredim s svojim telesom in kako lahko ustvarimo nekaj lepega in zanimivega, tudi ko ni popolnosti.

\section{Na treningih piliš tako tehniko kot fizično kondicijo. Je plesna tehnika za plesalca na vozičku drugačna?}

Precej drugačna in nimajo vse osebe na vozičku iste vrste invalidnosti. Jaz čutim noge, vendar nimam moči v njih, moja hrbtenica je za zdaj še v redu. Za fizično kondicijo bolj skrbim zunaj treningov, v studiu pa je pomembna tehnika. Douglas je odličen učitelj z zelo dobro tehniko, ki zna poslušati, saj je bil sam plesalec. Všeč mi je, ker nič ni nemogoče zanj, poskusil bo vse in to želi in zahteva tudi od plesalcev.

Kolikor vem, si zamenjala voziček in dobila pravega, plesnega in si bila zraven pri procesu načrtovanja in konstrukcije. Je voziček zdaj postal tvoj plesni čevelj ali si še vedno v obdobju loščenja in iskanja večje udobnosti in samozavesti, ko plešeš?

Našla sem izdelovalca invalidskih vozičkov, ki to dela po naročilu. Prinesla sem računalnik in mu pokazala vse videoposnetke naših treningov in nastopov. Tako je vedel, kaj hočem in kaj potrebujem, kako se giba moje telo in kje potrebuje več ali manj opore. Voziček je narejen po mojih merah in kot ulit zame in za moje plesne treninge. Material je močnejši in lahko izvedem tudi kakšno akrobacijo s soplesalci, tudi telesno sem bolj fleksibilna. To so moji plesni čevlji, ki jih ne zamenjaš, dokler ni vse preluknjano. Moja bolezen napreduje, zelo počasi, ampak vztrajno. Zavedam se, da so stvari, ki ji lahko naredim zadnjič. Ko sem šla zadnjič na Stone Mountain (hrib v okolici Atlante), sem vedela, da bo to moj zadnji vzpon brez vozička. Zaradi tega hočem dati vse od sebe, ko plešem, ker ne vem, ali bom lahko isto ponovila čez leto dni. Ne morem ostati v območju udobja, ples vedno ponuja nove izzive.

Full Radius Dance je profesionalna plesna skupina, usmerjena v sodobni ples. Te mika preizkusiti druge plesne sloge? Imaš to možnost v Atlanti?

Seveda bi plesala tudi kaj drugega. Obožujem swing in lindy hop in sem šla na nekaj tečajev, vendar sem jaz morala učiti druge, kako naj me držijo. Prva reakcija je strah; ljudje ne 
vedo, kako bi se približali plesalcu na vozičku, potem se navadijo, ampak mi smo tisti, ki moramo pristopiti k drugim. Tudi v sodobnem plesu je veliko slogov in različnih tehnik, ki me zanimajo. V Atlanti za zdaj ni druge izbire, mogoče v New Yorku malo več in San Franciscu. Rada bi se udeležila tudi drugih plesnih delavnic in seveda obiskala Evropo ter videla, kaj se dogaja na plesnem področju.

\section{Čeprav pozno, ni bilo prepozno zate. Vidim, da imaš še veliko načrtov v plesu, želja in ciljev.}

Upam, da bom lahko plesala še dolgo časa in da me ne bo ustavila moja bolezen, ampak moja starost. Rada bi odprla plesno šolo za otroke na invalidskih vozičkih in jim omogočila več priložnosti v plesu in gledališču. Kar nekaj let sem delala kot Montessori učiteljica, nasploh rada delam z mladimi. Za zdaj mislim, da mi še manjka prakse in moram še delati pri tehniki, obiskati več plesnih delavnic, ampak čez nekaj let se želim vrniti k pedagoškemu delu.

Lindy je članica plesne skupine Full Radius Dance, poleg tega piše svoj blog (Bend, Move, Sway) in članke za blog Rolling Without Limits, v prostem času pa se zavrti s Speakeasy Electro Swingom in The Artifice Clubom Atlanta.

Pogovarjala se je Monika Požek. 